\title{
Recent Approaches as Alternative Growth Promote to Replace Antibiotic in Animal Nutrition
}

\author{
Youssef A Attia* \\ ${ }^{1}$ Arid Land Agriculture Department, Faculty of Meteorology, Environment and Arid Land Agriculture, King Abdulaziz University, Saudi Arabia \\ ${ }^{2}$ Animal and Poultry Production Department, Faculty of Agriculture, Damanhour University, Egypt
}

*Corresponding author: Youssef A Attia, Arid Land Agriculture Department, Faculty of Meteorology, Environment and Arid Land Agriculture, King Abdulaziz University, PO Box 80208, Jeddah 21589, Saudi Arabia

Submission: February 27, 2018; Published: April 27, 2018

\author{
Summary \\ The purpose of this short article is to focus on the possible alternatives to antibiotic in animal nutrition for producing safe products and limit the \\ negative effects of antibiotics on the environment.
}

\section{Introduction}

Worldwide, animal products are main sources of protein, and poultry are the fastest growing sources of meat, representing nearly one fourth of all the meat produced globally. The modern production unit can produce market ready broiler chickens in about five weeks. This development arose from genetic selection, improved feeding and health management practices involving usage of antibiotics as therapeutic agents to treat bacterial diseases in intensive farming systems. They may also be used as prophylactic agents in the water of healthy chicks and as growth promoters at subtherapeutic concentrations in feed. Bacitracin, chlortetracycline, tylosin, avoparcin, neomycin, ox tetracycline, Virginiamycin and others are used for these purposes. Sub-therapeutic dosing in feed increase the rate of weight gains and improves the efficiency of converting feed to meat. The recommended levels of antibiotics in feed were $5-10 \mathrm{~g} / \mathrm{kg}$ in the 1950 's and have increased by ten to twenty folds since then.

During the last 50 years antibiotics were extensively used worldwide (Figure $1 \& 2$ ) as growth enhancer to improve animal performance, fight pathogens and eliminate culling [1-10]. The Maps above shows the widespread of using antibiotics as growth promoters in animal nutrition. However, during the last two decades there were public and governmental pressures to mimic the use of AGPs in animal nutrition. Thus, as shown in Table 1, some of the members of the Organization for Economic Co-operation and Development (OECD) countries have banned the use of antibiotic as growth enhancers in animal nutrition to eliminate health hazards and sustainable agriculture and environment.

Table 1 shows the regulation of the use of antibiotic growth enhancers in animal nutrition in the Organization for Economic Co-operation and Development OECD countries (source: as cited by
Kumar P et al., 2018; Antibiotic Free Chicken, https://en.engormix. com/poultry-industry/articles/antibiotic-free-chicken-t41857. htm, accessed March 27, 2018) from Telllant and Laxminarayan, 2015, Teillant, Aude and Laxminarayan R, 2015. Economics of antibiotic use in US swine and poultry production, CHOICES $1^{\text {st }}$ Quarter 2015, 30(1): 1-11).

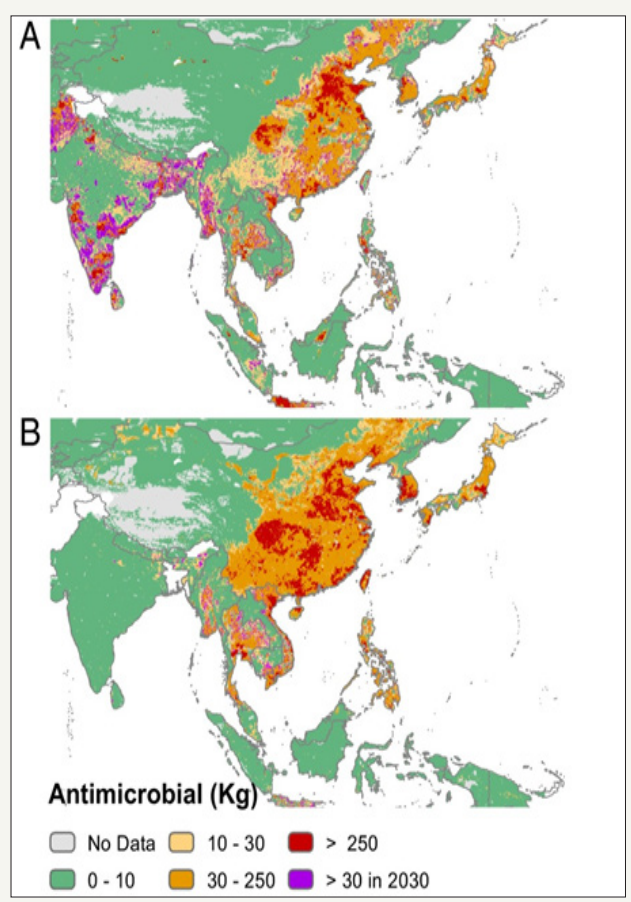

Figure 1: Antimicrobial consumption in chickens (A) and pigs (B) in 2010. Purple indicates new areas where antimicrobial consumption will exceed $30 \mathrm{~kg}$ per $10 \mathrm{~km} 2$ by 2030. Van Boeckel et al. [9]. 


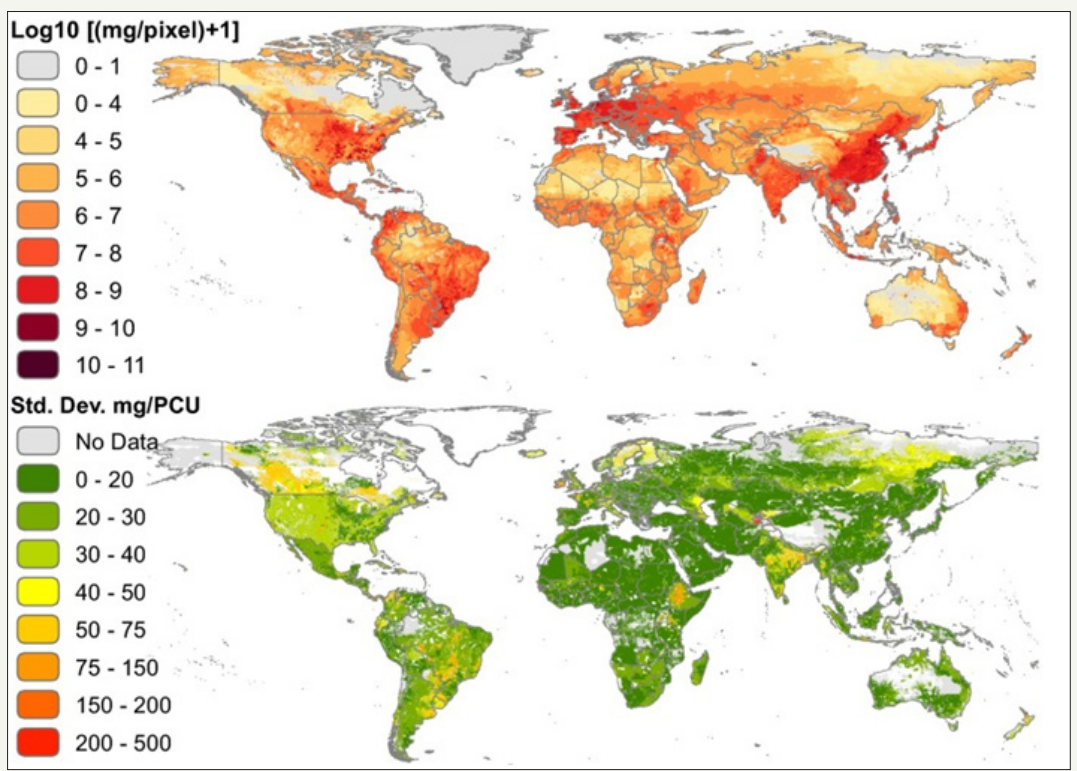

Figure 2: Global antimicrobial consumption in livestock in milligrams per $10 \mathrm{~km} 2$ pixels (Top) and average SD of estimates of milligrams per PCU Van Boeckel et al. (9).

Table 1: The regulation of the use of antibiotic growth enhancers in animal nutrition in the organisation for economic co-operation and development OECD countries (source: as cited by Kumar P 2018).

\begin{tabular}{|c|c|c|}
\hline $\begin{array}{c}\text { OECD } \\
\text { Country }\end{array}$ & Ban Of Antibiotic Growth Enhancer & Prescription Required To Use Antibiotic In Animals \\
\hline Australia & $\begin{array}{l}\text { No, but some AGPs ARE BANNED (fluoroquinolones, avoparcin, } \\
\text { virginiamycin, etc.) [Australian Commission on safety and Quality in health } \\
\text { care, 2013, https://www.safetyandquality.gov.au/]. }\end{array}$ & $\begin{array}{l}\text { Nearly all veterinary antibiotic can be sold on a } \\
\text { veterinarian prescription }\end{array}$ \\
\hline Canada & $\begin{array}{l}\text { No. The Canadian government issued a notice in April } 2014 \text { to stakeholders } \\
\text { mimicking the FDA approach to voluntarily phase out use of medically } \\
\text { important antibiotic as growth promoters [Government of Canada, 2014, } \\
\text { Federal action plan on antimicrobial resistance and use in Canada, http:// } \\
\text { healthycanadians.gc.ca/alt/pdf/publications/drugs-products-medicaments- } \\
\text { produits/antibiotic-resistance-antibiotique/action-plan-daction-eng.pdf?_- } \\
\text { ga=2.119983503.664858479.1519725596-573225208.1519725596] }\end{array}$ & $\begin{array}{l}\text { No. Plan to develop options to strength the veterinary } \\
\text { oversight of the use antibiotic }\end{array}$ \\
\hline Chile & No data & No data \\
\hline EU States & $\begin{array}{l}\text { Yes. All AGPs was prohibited in } 2006 \text { [European Union, 2003; http://europa. } \\
\text { eu/rapid/press-release_IP-05-1687_en.htm] }\end{array}$ & Yes \\
\hline Israel & No data & No data \\
\hline Japan & No [10] & Yes \\
\hline Mexico & $\begin{array}{l}\text { Yes, AGPs were banned in } 2007 \text { with some exceptions (avoparcin, } \\
\text { vancomycin, bacitracin, tylosin, virginiamycin, etc [10] }\end{array}$ & Yes \\
\hline New Zealand & $\begin{array}{l}\text { Yes, for the critically and highly important antibiotics listed by both WHO } \\
\text { and OIE (MAF NEW Zealand, 2011, A baseline survey of antimicrobial } \\
\text { resistance in bacteria from selected New Zealand foods, 2009-2010] }\end{array}$ & $\begin{array}{l}\text { Yes, for antibiotics identified with the potential for } \\
\text { resistance problems. }\end{array}$ \\
\hline South Korea & $\begin{array}{l}\text { Yes, since 211, AGPs use have been discontinued until a veterinary oversight } \\
\text { system can be put in place [USDA, 2011https://www.ers.usda.gov/amber- } \\
\text { waves/2015/november/restrictions-on-antibiotic-use-for-production- } \\
\text { purposes-in-us-livestock-industries-likely-to-have-small-effects-on-prices- } \\
\text { and-quantities/] }\end{array}$ & $\begin{array}{c}\text { Yes, the veterinary oversight system is currently being } \\
\text { developed. }\end{array}$ \\
\hline Turkey & No & No data \\
\hline USA & $\begin{array}{l}\text { No, the FDA released voluntary guidelines for the industry to withdraw the } \\
\text { use of medically important antibiotics as growth promoters [U.S. Food and } \\
\text { Drug Administration, 2013,http://www.nytimes.com/2013/12/12/health/ } \\
\text { fda-to-phase-out-use-of-some-antibiotics-in-animals-raised-for-meat.html] }\end{array}$ & $\begin{array}{l}\text { No, under the new FDA guidelines for industry, use } \\
\text { of medically impotent antibiotics will be under the } \\
\text { oversight of licensed veterinarians. }\end{array}$ \\
\hline
\end{tabular}


Phytogenic called photobiotic or botanicals, included herbs, spices and their products such as essential/violate oils and plant excretes are a group of natural growth promoters [NGPs] used as feed additives. They derived from herbs, spices or other plants to enhance livestock productivity, stimulation of appetite, improvement of digestibility by increasing endogenous digestive enzyme secretion and thus nutrient absorption, antioxidant, immune stimulant, antimicrobial and anthelminthic influences [1-3]. Phytogenic plants are good source of anti oxidants [46]. Additionally, they are safe for both living organisms and the environment, but the photogenic composition may vary widely due to method of processing, botanical origin, agronomical and environmental factors [7-10]. Medicinal herbs and their derivatives have many components that have anti-microbial, anti-oxidative, anti-allergic, anti-cancer, anti-mutagenic, hepato-protective and immune-modulate, they may also enhance economic performance, to gut eco-system, production yield, food quality, and fertility [23].

For example, Milk thistle [Silybum marianum L. Gaert., Asteraceae] seeds and Rosemary [Rosmarinus officinalis L.] leaves are new feed additives that may have promising effects. Milk Thistle has been utilized for long times by Theophrastus [ $4^{\text {th }}$ century BC] who was possibly the first to define it under the name of "Pternix" and later it was cited by Dioskurides in his "Materiamedica" and by Plinius [ $1^{\text {st }}$ century AD] [11-13]. Silymarin is a flavonoids mixture extracted from milk thistle seeds (MTS), which contains silybin, silydianin and silychristin; molecules that show estrogenic effect in ovariectomized rats [14] and its major component, silibinin, bind to cytosolic estrogen receptors [15]. Milk thistles process powerful anti-oxidants [16]. Silymarin is the active constituent in milk thistle seeds and represent about $4-6 \%$ of the milk thistle seed extract [17]. Other beneficial health components in MTS are fixed oil and free fatty acids and proteins, silybonol, apigenin, flavonolignans and betaine. The MTS was utilized in Europe for many centuries for liver and gall bladder dysfunction treatments [18]. The enhancing effect of silymarin is mediated through increasing endogenous antioxidant defenses, such as those mediated by glutathione system and superoxide dismutase [SOD] [19]. Silymarin is an outstanding scavenging reactive oxygen spices [ROS], antioxidant. In addition, repeated doses of extract of milk thistle extract significantly decreased biomarker [enzymes] of liver leakages while increased antioxidant enzymes of rat liver homogenate, showing free radical scavenger potential [20]. Also, lipid peroxidation controlling thereby defending cells against oxygen species [21].

Another example of potential phytogenic with multipurposes application is the Rosemary leaves. Rosemary is rich source of antioxidant substances such as rosmarinic acid and caffeic acid [22]. Rrosmarinic acid is well absorbed in the gut and from the skin, decreases the creation of leukotriene B4 in human polymorph nuclear leukocytes and prevents the complement system [23]. Furthermore, revealed that rosemary essential oil enriches rat hepatocytes' resistance against DNA-damaging oxidative agents and effective agent for scavenging free radicals [24]. Caffeic acid and rosmarinic acid have a potential for inflammatory diseases and hepatotoxic treatments [25]. Rosemary is rich in photochemical derivatives such as triterpenes, flavonoids and apolyphenol. Carnosol, rosmanol and epirosmanol phenolic diterpenes of rosemary control peroxidation of unsaturated lipids [26]. Moreover, rosemary significantly decreased the elevation in peroxidation of unsaturated lipids and boosted the levels of reduced glutathione and antioxidant enzyme actions in the kidney and testis in comparison to aspartame controls [27].

\section{Conclusion}

Research for alternative to antibiotic is an essential task in animal nutrition and can lead to replace antibiotic, safe animal products and econ-friendly environment. However, it seems that looking for complex formulas based on their active substances of different photogenic plan and/or their products may lead to constant and better results [28]. The use of probiotics, prebiotics, synbiotic, enzymes and organic acids are possible alternatives although further research is essential. The future of using phylogenic could be extended to alleviate the stressful condition and improve immunity [5,28].

\section{References}

1. Attia YA, Allakany HF, Abd Al-Hamid AE, Al-Saffar AA, Hassan RA, et al. (2013) Capability of different non-nutritive feed additives on improving productive and physiological traits of broiler chicks fed diets with or without aflatoxin during the first 3 weeks of life. J Anim Physiol Anim Nutr (Berl) 97(4): 754-772.

2. Attia YA, Bovera F, El-Tahawy` WS, El-Hanoun AM, Al-Harthi MA, et al. (2015) Productive and reproductive performance of rabbits does as affected by bee pollen and/or propolis, inulin and/or mannanoligosaccharides. World Rabbit 23(4): 273-282.

3. Attia YA, Bovera F, Abd El-Hamid AE, Tag El-Din AE, Al-Harthi MA, et al. (2016) Effect of zinc bacitracin and phytase on growth performance, nutrient digestibility, carcass and meat traits of broilers. J Anim Physiol Anim Nutr (Berl) 100(3): 485-491.

4. Attia YA, Al-Harthi MA, and Hassan SS (2017) Turmeric (Curcuma longa L.) as a phytogenic growth promoter alternative for antibiotic and comparable to mannan oligosaccharides for broiler chicks. Rev Mex Cienc Pecu 8(1): 11-21.

5. Attia YA, Bakhashwain AA, Bertu Nehal K (2017) Thyme oil (Thyme vulgaris $\mathrm{L}$.) as a natural growth promoter for broiler chickens reared under hot climate. Italian Journal of Animal Science 16(2): 275-282.

6. Attia YA, Al-Khalifa H, Ibrahim MS, Abd Al-Hamid AE, Al-Harthi MA, et al. (2017) Blood hematological and biochemical constituents, antioxidant enzymes, immunity and lymphoid organs of broiler chicks supplemented with propolis, bee pollen and mannan oligosaccharides continuously or intermittently. Poult Sci 96(12): 4182-4192.

7. Attia YA, Hamed RS, Bovera F, Abd El-Hamid AE, Al-Harthi MA, et al. (2017) Semen quality, antioxidant status and reproductive performance of rabbits bucks fed milk thistle seeds and rosemary leaves. Anim Reprod Sci 184: 178-186.

8. Attia YA, Abd El-Hamid AE, De Oliveira MC, Kamel KI, Qota EM, et al. (2018) Soya lecithin and season affect the productive performance, nutrient digestibility, and blood constituents of growing rabbits. Journal of Animal and Feed Sciences 27(1): 36-43.

9. Van Boeckel TP, Brower C, Gilbert M, Grenfell BT, Levin SA, et al. (2015) Global trends in antimicrobial use in food animals. Proc Natl Acad Sci USA 112(18): 5649-5654. 
10. Moran GJ, Abrahamian FM, Lo Vecchio F, Talan DA (2013) Acute bacterial skin infections: developments since the 2005 Infectious Diseases Society of America (IDSA) guidelines. J Emerg Med 44(6): e397-e412.

11. Athanasiadou S, Kyriazakis I (2007) Medicinal plants for helminthes parasite control: facts and fiction. Animal 1: 1392-1400.

12. Castanon J (2007) History of the use of antibiotics as growth promoters in european poultry feeds. Poult Sci 86(11): 2466-2471.

13. Windisch W, Kroismayr A (2007) The effects of photobiotic on performance and gut function in monogastrics.

14. Kren V, Walterov D (2005) Silybin and silymarin- new effects and applications. Biomed Pap Med Fac Univ Palacky Olomouc Czech Repub 149(1): 29-41.

15. Kummer V, Maskov J, Canderle J, Zral y, Neca J, et al. (2001) Estrogenic effects of silymarin in ovariectomized rats. Veterinary Medicine Czech 46: 17-23.

16. Seidlov'a-Wuttke D, Becker T, Christoffel V, Jarry H, Wuttke W (2003) Silymarin is a selective estrogen receptor $\beta(\mathrm{ER} \beta)$ agonist and has estrogenic effects in the metaphysis of the femur but nor anti estrogenic effects in uterus of ovariectomized (ovx) rats. J Steroid Biochem Mol Biol 86: 179-188.

17. Wu JW, Lin LC, Tsai TH (2009) Drug-drug interactions of silymarein on the perspective of pharmacokinetics. J Ethnopharmacol 121(2): 181193.

18. Greenlee H, Abascal K, Yarnell E, Ladas E (2007) Clinical applications of silybum marianum in Oncology. Integr Cancer Ther 6(2): 158-65.

19. Surai PF (2015) Silymarin as a natural antioxidant: An overview of the current evidence and perspectives antioxidants (Basel) 4(1): 204-247.

20. Ramadan S, Shalaby M, Afifi N, El-Banna H (2011) hepatoprotective and antioxidant effects of silybum marianum plant in rats. International Journal for Agro Veterinary and Medical 5(6): 541-547.

21. Kshirsagar M, Mahash V, Srinivas P, Mangala L (2012) Evaluation of the protective effect of silymarene on doxorubicin induced chronic testicular toxicity in Rats. International Journal of Pharmacy and Biological Sciences 4: 473-484.

22. Herrero M, Arraez Roman D, Segura A, Kenndler E, Giusr B, et al. (2005) Pressurized liquid extraction-capillary electrophoresis-mass spectrometry for the analysis of polar antioxidants in rosemary extracts. J Chromatogr A 1084(1-2): 54-62.

23. Ramirez P, Senorans F, Ibanez E, Reglero G (2004) Separation of rosemary antioxidant compounds by supercritical fluid chromatography on coated packed capillary columns. Journal of Chromatography A 1057(1-2): 241-245.

24. Harvàthová E, Slameňová D, Navarová J (2010) Administration of rosemary essential oil enhances resistance of rat hepatocytes against DNA-damaging oxidative agents. Food Chemistry 123(1): 151-156.

25. Katerinopoulos H, Pagona G, Afratis A, Stratigakis N, Roditakis N (2005) Composition and insect attracting activity of the essential oil of Rosmarinus officinalis. J Chem Ecol 31(1): 111-122.

26. Zeng W, Wang S (2001) Antioxidant activity and phenolic compounds in selected herbs. J Agric Food Chem 49(11): 5165-5170.

27. Hozayen W, Soliman H, Desouky E (2014) Potential protective effects of rosemary extract, against aspartame toxicity in male rats. International Journals of Multidisciplinary Research Academy 31(2): 2320-5083.

28. Selvam R, Suresh S, Saravanakumar M, Chandrasekaran CV, Prashanth D (2018) Alleviation of Heat Stress by a Polyherbal Formulation, Phytocee $^{\mathrm{TM}}$ : Impact on Zootechnical Parameters, Cloacal Temperature, and Stress Markers. Pharmacognosy Res 10(1): 1-8.
Creative Commons Attribution 4.0

International License

For possible submissions Click Here

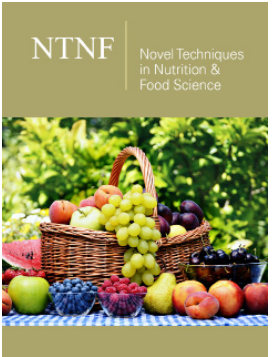

Novel Techniques in Nutrition and Food Science

\section{Benefits of Publishing with us}

- High-level peer review and editorial services

- Freely accessible online immediately upon publication

- Authors retain the copyright to their work

- Licensing it under a Creative Commons license

- Visibility through different online platforms 